\title{
How to be an engaged intellectual: Case studies and reflections
}

\author{
George Jacobs \\ george.jacobs@gmail.com \\ Centre for a Responsible Future, Singapore
}

\begin{abstract}
Engaged intellectuals, for the purposes of this paper, are academics who ask themselves what they can do to maximize the role of their academic and other activities in making the world a better place. This paper recounts and reflects on the experiences of the author and others as they have attempted to put their academic and other skills and understandings to the service of the greater good. These experiences touch on such areas as wildlife conservation, gendered images, the relative role of individuals in social change, Social Interdependence Theory, student centered education, free online publications, Creative Commons, Communities of Practice, organizations of intellectuals, poverty alleviation, plant-based eating, and the Fourth Industrial Revolution. The paper also discusses the author's own sizeable inadequacies in his attempts to be an engaged intellectual and the difficulties academics face in changing the world from their place in academia. The author concludes by encouraging intellectuals to make frequent trips outside the familiar comforts of the ivory tower to engage with others in using the many wonders of the modern and natural world to address the many challenges we face.
\end{abstract}

Keywords: intellectuals, academics, engaged, activist, social change 


\section{Introduction}

This article focuses on how intellectuals can be of service to society generally. The definition of 'intellectuals' used here includes people who are associated with academic institutions, such as universities and research centres. Typical activities for intellectuals include publishing in academic publications, rather than in the popular media, and presenting to other intellectuals at academic conferences, rather than sharing with audiences of laypeople. For many years, intellectuals have been seen negatively as people who isolate themselves in ivory towers, studying whatever whets their curiosity, ignoring the needs of the larger society. The stereotype of these ivory tower intellectuals pictures people who have "an impractical often escapist attitude marked by aloof lack of concern with or interest in practical matters or urgent problems" (Ivory tower, 2019). Teachers, including primary school teachers, can be seen as intellectuals in the negative sense of the term, as to some elements of society, the role of teachers lies in preparing students for exams, rather than for real life.

In contrast to ivory tower intellectuals are engaged intellectuals (Rothschild, 2003). These people devote their efforts to improving the world around them. Jones (n.d.) defined an engaged intellectual as someone:

who is intensely curious about the world around her, constantly in the act of researching people, herself, and the politics of social interactions and injustices, working as an educator either formally or informally to bring people together for reasons of solidarity, and consciously merging "intellectual" theory and everyday practice in life/pedagogy to work for social change.

An example of the work of engaged intellectuals is Suppiah and Kaur (2018), who used their academic skills to investigate the situation of female transnational sex workers in Malaysia. The authors noted that these workers suffer from stigmatization and discrimination. By conducting their study, which looked in part at research methodology, the researchers contributed to the larger academic literature, while at the same time shining a light on the dire situation of the migrant sex workers and thereby perhaps helping to improve their conditions or allow them to return to their home countries and take up less dangerous, higher status employment.

How to be an engaged intellectual? The website " 80,000 hours" (https://80000hours.org) derives its name from the fact that an average working career encompasses about 80,000 hours of 
people's (intellectuals and others) lives. The website provides advice on how people can best use their careers in the service of the wider society. Of course, the question of what benefits and harms the greater good sparks many controversies, as most or even all issues and problems have a number of often contradictory proposals for addressing them (Effective altruism, 2016). For instance, to deal with the climate crisis, proposals include preparing to move to Mars ("This speculative SpaceX", 2018), reducing consumption of food from nonhuman animals, eating only locally grown food, and lessening the use of air travel. Additionally, some experts claim global warming is a hoax or not caused by humans. Furthermore 'engaged' can suggest a wide range of commitment, from voting once every four or six years or donating $\$ 10$, all the way to people quitting their tenured professorships to start new charities.

\section{Background on a Case Study of Being an Engaged intellectual}

This section focuses on some work by the author of this article, someone who strives to be an engaged intellectual, although his practice leaves much to be desired both as to the quality of his intellectual output and the quantity of time in which he engages in social service efforts. The case began with a 2019 incident. For the past three years, the author had travelled once a year from his home in Singapore to northern Malaysia for a few days in support of MYCAT (Malaysian Conservation Alliance for Tigers) - https://www.citizenactionfortigers.my/ - an NGO that works to protect the endangered Malayan Tiger by reducing poaching and habitat loss.

During his 2019 Malaysia trip, an incident occurred in another part of Malaysia in which two tigers walked into a rural village. Although no one was hurt - tigers or humans - a good deal of media attention was generated. Unfortunately, the media coverage reflected anthropocentric (Quinn, Castéra, \& Clement, 2016), i.e., human-centric, views prioritizing the welfare of humans and largely ignoring the plight of the tigers.

The author of the current paper, who has a doctorate in Education, recognized this incident as a potential teachable moment (O'May, Gill, McWhirter, Kantartzis, Rees, \& Murray, 2016), i.e., a time when people may be particularly ready to learn information or change attitudes. He also has a master's degree in Linguistics and considerable experience with formal writing, both as a teacher of writing and as a writer for academic journals, etc. Perhaps, he thought, these writing and language analysis skills might be of use. His first action in response to the tiger incident was 
to help a more active member of MYCAT write and publish an article (D'Rozario, 2019) in a leading online media outlet: Channel News Asia.

Then, he wrote an ecolinguistic analysis of the online media coverage of the tiger incident, highlighting the anthropocentrism of the coverage, providing specific language examples, such as instances in which tigers were portrayed as objects to be owned by humans, as fearsome creatures seeking to attack humans, as objects of entertainment for humans, and as criminals (Jacobs \& Fong, 2020). Also highlighted in the analysis of the media coverage was the lack of background information about humans' role in the tigers' endangered status. Furthermore, the article provided examples of a less anthropocentric view of wild animals among some people in India.

While the manuscript was accepted for publication, the research presented therein was not a sterling example of ecolinguistic analysis. According to International Ecolinguistics Association (IEA, 2019), ecolinguistics shows "how linguistics can be used to address key ecological issues, from climate change and biodiversity loss to environmental justice." Separate from the manuscript review process, the author also sent the manuscript to a member of the IEA board for feedback, and that person recommended that it needed substantial modification to attain an adequate standard of linguistic analysis. In the past, the author has attempted to collaborate with more skilled linguists, sometimes with success (e.g., Gilquin \& Jacobs, 2006; Jacobs, Goatly, \& Ming, 2005) and other times unsuccessfully.

While acceptance of the manuscript constituted a victory for the author's efforts to be an engaged intellectual, another problem, in addition to the less-than-stellar quality of the research, was that while the popular press often publishes within a few days of receipt of a letter or manuscript, the academic press can be much slower, even in the case of online journals. First, once journals receive manuscripts, they must be sent for review by unpaid reviewers who often require several months to give their feedback on the quality of the manuscript and as to whether to publish it. Next, even if manuscripts are accepted to be published, revisions are often needed before publication. In the present case, the academic journal is scheduled to be published approximately five months after the incident took place, which is still much faster than average, in the author's experience. 


\section{Addressing Students' Body Image}

The present section of this article on being an engaged intellectual looks at another area of scholarship which provides a rich vein of issues for engaged intellectuals to address: gender. Roughly, the terms 'gender' and 'sex' can be differentiated in that 'gender' focuses on social and cultural factors, while 'sex' distinguishes people based on physical characteristics. An area related to gender that scholars have investigated involves the information the media communicates about how females should look and behave. An often cited example of such media are what have come to be called Disney Princess films, movies produced over many years, since the mid- $20^{\text {th }}$ century, with young female heroes (Azmi, Rashid, \& Wahab, 2018). These films include Snow White and the Seven Dwarfs, Sleeping Beauty, Cinderella, and Beauty and the Beast. Not only do the films portray a fixed and stereotyped image of the ideal female personality as sweet and reserved, but they also communicate a fixed view of what females should look like.

This gendered view of females supported females' second-class role in society and caused a great deal of stress, especially for those females who did not fit or did not want to fit into the stereotype. The Disney films mentioned earlier are all from the $20^{\text {th }}$ century. Fortunately, the current century has witnessed changes toward a more varied depiction of Disney's female heroes. These changes parallel larger social changes that have witnessed some progress in females' status, although much more progress remains to be made both in the films and in society generally.

Females are not the only members of society who suffer from gendered demands on how to behave and look: so too do males, for whom the ideal image is that of a tough, aggressive person, with a large, muscular body. Numerous films and other media portray this image. Ones from the $20^{\text {th }}$ century include the Rocky movies and many of the same Disney films mentioned above, such as Beauty and the Beast. These stereotypes of male behaviour and appearance put great pressure on males to conform (Barlett, Vowels, \& Saucier, 2008). Fortunately, some progress has also been made in social acceptance of a wider variety of male roles, and these changes are reflected in the media. Despite this progress in freeing people from gendered stereotypes, these straitjacketing images persist in the media, both traditional and social, as well as in many other areas of society. Denny (2019), a mathematics teacher in the U.S. who taught females and males about 13 years old, decided to intervene. Below is a summary of a mini-unit her class did which integrated mathematics, thinking skills, social justice, and communication. Additionally, the unit fulfilled a 
vital role for engaged intellectuals by linking their efforts with meaningful change in the world beyond academia.

The main mathematics and thinking skills goal was to increase students' ability to do proportional thinking. To work toward this goal, students did calculations to compare, on one hand, dolls, such as Barbie (representing an idealized female), and action figures, such as Batman (representing an idealized male), with, on the other hand, average human bodies. The social justice curricular goal of the unit was addressed by students seeing the huge differences between the idealized images of the dolls and action figures compared to normal people. Reading two articles on the topic from the popular media bolstered students' understanding.

Discussion helped students consider different perspectives on the issue. For example, one student argued that the disproportion was not problematic, because dolls and action figures are not meant to be realistic. In response, a classmate presented another view, “[E]ven if girls don't actually think that we have to look exactly like Barbie, she's one of many ways that girls are pressured to be skinny and have big breasts. We're getting sold unrealistic images of what bodies should look like all the time." This same student continued, "[T]hey make commercials with real live models and then airbrush and photoshop them to make girls skinnier and curvier, make men have more pronounced six packs and jawlines."

Communication constituted yet another curricular goal of the unit, because when students share what they learn with others, these students are more likely to see themselves as part of a larger learning community (Jessup-Anger, Armstrong, Kerrick, \& Siddiqui, 2019). Toward this aim, students participated in their school's annual Social Justice Data Fair. To do so, they made posters and interactive materials, such as a life-size model of Roller-Skating Barbie's skirt so that students and teachers could hold up the skirt against their own bodies to experience exactly how small and unnatural Barbie's skirt was.

\section{Who Are the Heroes?}

Kenney (2019) provided another area of scholarship that engaged intellectuals might consider: the question of how social change occurs. She began by discussing the long-time presence in literature of what has been called "the hero's journey," with this term popularized by Campbell (2003). The hero's journey view mirrors the "great man theory of history" (Kristian, 2019), i.e., history is made by individuals, usually males, rather than by large groups consisting of both females and males. 
This great man perspective predominates in many accounts of history, e.g., political and military leaders win wars and carry out important changes that shape the destiny of a country and the wider world. Furthermore, it seems simpler to identify one person as the leader, the key person in any organization or movement.

In contrast to such an individuals-as-shapers-of-history view, Kenney argued that social movements, rather than succeeding or failing based on the creativity and effort of one or two leaders, sink or swim due to the collective intelligence and industry of many people. Such a view fits with the idea of distributed leadership (Gronn, 2002), i.e., that everyone can and should be a leader. For example, as this paper is being written, a large movement has arisen for action to address the climate crisis, and by far the best-known figure in these efforts is a teenager, Greta Thunberg. However, Thunberg attempts to share the limelight with others.

Kenney's approach fits with the current paradigm in education, psychology, and other fields. In education, for instance, many educators and researchers have found useful guidance from Sociocultural Theory (Vygotsky, 1978), which highlights the social nature of learning and the role of communication, e.g., Webb found that when students used explanations to teach each other, learning increased both for those doing the explaining and for those receiving the explanations. In a similar vein, Social Constructivism (Palincsar, 1998) maintains that although each person constructs their own unique understanding of the world, their environment, including the people in that environment, play a powerful role in shaping that understanding.

In psychology, prominent theories that emphasize the social impact on individuals include Humanistic Psychology (Maslow, 1968), which sees relationships as crucial to a fulfilling life, and Multiple Intelligences Theory (Gardner, 1993), which includes interpersonal intelligence, i.e., the desire to and skill at cooperating with others, as a key intelligence, although at the same time not discounting intrapersonal intelligence, i.e., comfort with spending time alone, as well as the ability to understand oneself.

Of course, sociology must be taken into account when considering the power of social elements. A prominent theory that incorporates sociology, psychology, and education is Social Interdependence Theory (Johnson \& Johnson, 2009). This theory looks at what leads people to care about the success of others. Do people feel that the outcomes of themselves and others are positively correlated, i.e., what aids one aids the others / what hurts one hurts the others, or negatively correlated, i.e., what aids one hurts the others / what hurts one aids the others, or 
uncorrelated, i.e., the impact on one has no impact on the others? Those implementing Social Interdependence Theory, attempt to increase people's feelings of being positively interdependent with others. Examples of engaged intellectuals doing such work include Aronson (2019) among students of different races at the same school and Allport (1954) among people of different races in the same community.

All of the above theories go back at least 30 years to the time when scholars had to speculate about what was happening inside people's brain. Now, neuroscientists have increasingly sophisticated and portable tools to actually look inside the brain. What they have found confirms what previous theorists postulated about the brain's social nature. In fact, some neuroscientists, e.g., Lieberman (2013), call themselves social cognitive neuroscientists, and Lieberman posited that one of humans' key weaknesses (he labelled it our kryptonite) is our unwillingness or inability to appreciate the power of the social.

To summarize this section on who are the heroes in social change, we want to include everyone, to value everyone's participation. That is the essence of the concept of Community of Practice (Kevany \& MacMichael, 2014; Wenger, 1998). Everyone, regardless of whether they are a novice or an expert, regardless of whether they are a celebrity or a"nobody," is valued, is informed, is welcome to voice their views. In this spirit, engaged intellectuals do not sit on some gilded throne, like in an ivory tower; instead, they participate as do others.

\section{Not Only the What; Also the How}

Engaged intellectuals often take part in teaching, whether it is formal education in some institution, such as a primary school or a university, or other formats. In fact, education can also be non-formal or informal (Eshach, 2007). Non-formal education involves planned learning but not as part of an institution that primarily focuses on education, and usually not for a degree or diploma. An example of non-formal learning would be a public speaking class taught at a community center. Perhaps learning on the internet, e.g., learning to improve your poster-making skills via watching instructional videos on Youtube, could be considered non-formal learning. Informal education takes place everywhere and without professional teachers, e.g., aunts and uncles might teach their nephews and nieces about other religions, or the nephews and nieces might do the teaching, for instance, about how to use a particular app. In informal education, everyone teaches, including self-teaching. 
Many different approaches to teaching exist informed by a variety of theories and philosophies on education and society generally. Perhaps the best known distinction between approaches to pedagogy involves that between teacher centered and student centered. Table 1 from Jacobs and Renandya (2019, p. 5) briefly describes some of the continua along which the two approaches vary.

Table 1: Selected continua of characteristics on which to compare teacher centered learning and student centered learning.

\begin{tabular}{|c|c|}
\hline Teacher Centered Learning & Student Centered Learning \\
\hline $\begin{array}{l}\text { 1. Teachers and course materials are seen as } \\
\text { all knowing; knowledge is seen as fixed }\end{array}$ & $\begin{array}{l}\text { Teachers and course materials can be wrong; } \\
\text { teachers are co-learners along with students; } \\
\text { knowledge is changeable and subject to } \\
\text { debate }\end{array}$ \\
\hline $\begin{array}{l}\text { 2. Students talk is mostly directed at teachers, } \\
\text { i.e., teacher-student interaction }\end{array}$ & $\begin{array}{l}\text { Students also talk to peers, i.e., peer } \\
\text { interaction }\end{array}$ \\
\hline $\begin{array}{l}\text { 3. Teachers and administrators are the only } \\
\text { ones who decide what will be studied and } \\
\text { how it will be studied }\end{array}$ & $\begin{array}{l}\text { Students also have a voice in what they will } \\
\text { study and how they will study it }\end{array}$ \\
\hline 4. Assessment is done only by teachers & $\begin{array}{l}\text { Students also do assessment: of peers, selves, } \\
\text { and their classes }\end{array}$ \\
\hline $\begin{array}{l}\text { 5. Learning tasks are seen as preparation for } \\
\text { what students will do after their education }\end{array}$ & $\begin{array}{l}\text { Learning tasks can also connect to students' } \\
\text { lives in the present }\end{array}$ \\
\hline $\begin{array}{l}\text { 6. Extrinsic motivation is the dominant form } \\
\text { of motivation }\end{array}$ & $\begin{array}{l}\text { Teachers and students attempt to build } \\
\text { intrinsic motivation }\end{array}$ \\
\hline $\begin{array}{l}\text { 7. Most questions/tasks have only one correct } \\
\text { answer; students are to repeat what they have } \\
\text { been taught }\end{array}$ & $\begin{array}{l}\text { Many questions/tasks have multiple correct } \\
\text { answers; students are to go beyond what they } \\
\text { have been taught and to thereby develop } \\
\text { thinking skills }\end{array}$ \\
\hline $\begin{array}{l}\text { 8. One way of teaching, the didactic method, } \\
\text { predominates }\end{array}$ & Multiple ways of teaching are used \\
\hline $\begin{array}{l}\text { 9. The focus is almost exclusively on } \\
\text { cognitive outcomes, such as test scores }\end{array}$ & $\begin{array}{l}\text { Students and teachers also value affective } \\
\text { outcomes, such as enthusiasm for learning } \\
\text { and empathy for others }\end{array}$ \\
\hline
\end{tabular}


In general, teaching that encourages student activity, critical thinking, creativity, democracy, and student input in shaping their own learning falls along the student centered side of the above continua. Indeed, in the following table, Jacobs and Renandya (2019, p. 6) argued that student centered learning promotes more equitable societies.

Table 2: Links between characteristics of student centered learning and characteristics of a more equitable society

\begin{tabular}{|l|l|l|}
\hline $\begin{array}{c}\text { Student Centered } \\
\text { Learning }\end{array}$ & \multicolumn{1}{|c|}{$\begin{array}{c}\text { Explanation of Student } \\
\text { Centered Learning } \\
\text { Characteristics }\end{array}$} & \multicolumn{1}{|c|}{ More Equitable Society } \\
\hline $\begin{array}{l}\text { Students and } \\
\text { Teachers as } \\
\text { Co-Learners }\end{array}$ & $\begin{array}{l}\text { Teachers do not pretend to know } \\
\text { everything. Instead, teachers and } \\
\text { students learn along with each } \\
\text { other. }\end{array}$ & $\begin{array}{l}\text { Rulers are not seen as all knowing. } \\
\text { They at least pretend to be learning } \\
\text { and to seek input from the } \\
\text { population }\end{array}$ \\
\hline $\begin{array}{l}\text { Student-Student } \\
\text { Interaction }\end{array}$ & $\begin{array}{l}\text { Students believe that they can } \\
\text { learn from peers and develop the } \\
\text { skills for doing so. Learning with } \\
\text { peers constitutes a key mode of } \\
\text { student learning. }\end{array}$ & $\begin{array}{l}\text { People have more freedom to } \\
\text { assemble, to form unions, political } \\
\text { parties, etc. }\end{array}$ \\
\hline Learner Autonomy & $\begin{array}{l}\text { Teachers act as guides on the side, } \\
\text { as students learn how to become } \\
\text { lifelong learners. }\end{array}$ & $\begin{array}{l}\text { People can make choices about } \\
\text { their lives }\end{array}$ \\
\hline Focus on Meaning & $\begin{array}{l}\text { The class does not use rote } \\
\text { learning. Instead, students fully } \\
\text { understand what they are studying } \\
\text { and why. }\end{array}$ & $\begin{array}{l}\text { People understand } \\
\text { governments and others do what } \\
\text { they do, rather than people } \\
\text { following blindly }\end{array}$ \\
\hline $\begin{array}{l}\text { Curricular } \\
\text { Integration }\end{array}$ & $\begin{array}{l}\text { Students appreciate the links } \\
\text { between what they study one day } \\
\text { in one class with other days in the } \\
\text { same class and the same day in } \\
\text { different classes. }\end{array}$ & $\begin{array}{l}\text { In line with learner autonomy and } \\
\text { curricular integration, people can } \\
\text { inform themselves and } \\
\text { transparency helps them be } \\
\text { informed so that they can make } \\
\text { reasoned decisions about what } \\
\text { affects them. }\end{array}$ \\
\hline
\end{tabular}




\begin{tabular}{|c|c|c|}
\hline Diversity & $\begin{array}{l}\text { Teachers and students plan } \\
\text { learning activities with the needs } \\
\text { of all students in mind, and the } \\
\text { class appreciates the benefits of } \\
\text { learning with diverse students and } \\
\text { teachers. }\end{array}$ & $\begin{array}{l}\text { Societies provide more equal } \\
\text { opportunities, and differences } \\
\text { among groups and individuals are } \\
\text { respected. }\end{array}$ \\
\hline Thinking Skills & $\begin{array}{l}\text { The class goes beyond the } \\
\text { information given, as they } \\
\text { elaborate on the ideas and } \\
\text { information they } \\
\text { encounter. }\end{array}$ & $\begin{array}{l}\text { People engage in reasoned } \\
\text { respectful exchanges of view. }\end{array}$ \\
\hline $\begin{array}{l}\text { Alternative } \\
\text { Assessment }\end{array}$ & $\begin{array}{l}\text { Assessment expands beyond } \\
\text { multiple choice, true-false, and } \\
\text { short answers. Students take part } \\
\text { in the assessment process. }\end{array}$ & $\begin{array}{l}\text { People appreciate each other's } \\
\text { varied talents and take } \\
\text { opportunities for developing } \\
\text { existing and new talents. They } \\
\text { view failure as a stepping stone } \\
\text { toward success. }\end{array}$ \\
\hline Learning Climate & $\begin{array}{l}\text { The class cooperates toward an } \\
\text { atmosphere in which all are } \\
\text { appreciated and all are willing to } \\
\text { take risks. }\end{array}$ & $\begin{array}{l}\text { A sense of community prevails a } \\
\text { various levels of society, including } \\
\text { internationally. }\end{array}$ \\
\hline Motivation & $\begin{array}{l}\text { Rather than extrinsic motivation } \\
\text { dominating, the class strives to } \\
\text { promote intrinsic motivation, } \\
\text { where everyone is a motivator of } \\
\text { their individual self and their } \\
\text { peers. }\end{array}$ & $\begin{array}{l}\text { People contribute to society from } \\
\text { a spirit of good will, more than to } \\
\text { achieve rewards or to avoid } \\
\text { punishments. }\end{array}$ \\
\hline
\end{tabular}

To go into more detail on just one area of the compatibility between student centered learning and the kind of society that engaged intellectuals might envision, it can be suggested that student centered learning resonates with democracy in the society beyond the school (Jacobs \& Power, 2016). Below each of four selected elements of democracy are discussed in terms of their congruence with student centered learning.

a. Shared Decision Making - Democracy gives citizens some decision-making powers, e.g., the British voters' 2016 decision to leave the European Union. Regardless of whether one agrees with the British voters' decision, it shows the power of people in a democracy. Student centered learning gives students power in some areas, e.g., they take part in 
assessing their peers' and their own work, and students have some choice on the topics for their projects and what they read for extensive reading (Extensive Reading Foundation, (n.d.).

b. Shared Knowledge Generation - In democracies, citizens provide information to be included in the decision-making process. In student-centered learning, students provide some of the materials used in their studies, e.g., instead of all the questions coming from teachers, students can also generate questions to be responded to by themselves, peers, and teachers.

c. Diversity Embraced - Diversity takes many forms in societies and education. One aspect of diversity involves diversity of ideas. In a democracy, everyone should have the same responsibilities and rights. However, in education when right-or-wrong answers and closeended questions predominate, opportunity for diversity diminishes. In contrast, a focus on a variety of possible good answers and open-ended questions tends to enhance diversity (Attali, Laitusis, \& Stone, 2016).

d. Cooperation - When the predominant feeling among various elements of society can be characterized as one of competition or disinterest, society functions less well. Sadly, some leaders promote such disharmony. In education, student centered learning promotes cooperation, not competition or disinterest, e.g., through the frequent use of student-student interaction that is structured to foster feelings of positive interdependence. Furthermore, when students, just like citizens, cooperate, they can have a stronger voice in what happens around them.

\section{Brainstorming Suggestions for Being More Effective Engaged Intellectuals Spreading Ideas Faster and Wider}

The current section of this article presents ideas for being more effective engaged intellectuals. First, several means could be used to address the problem of disseminating information and perspectives more quickly and to a wider audience. Prepublication (Birney, et al., 2009) provides one such means. In prepublication, data and early writeup of a study or paper are shared before formal publication. One form of prepublication can be done via commercial social networking websites, such as Academia.edu, which allow academics to solicit feedback on the papers that they post. Advantages of prepublication include that other scientists, as well as other interested parties 
generally, can improve the work by contributing their own insights and experience, as well as serving the role of critical friends (Kind, 2016), i.e., people who give constructive, supportive feedback. Furthermore, prepublication can inspire and inform readers. For example, perhaps other linguists will want to use their skills to analyze texts about tigers and other nonhuman animals.

In addition to disseminating engaged scholarship faster, another goal is to distribute in more widely. Two ways to do that are to publish in open access journals and via creative commons. Open access journals (Conte, 2019) are those available to anyone with internet access. In contrast, many academic journals are owned by publishers who charge a fee to those who wish to read articles. Universities and even governments in wealthier countries may purchase subscriptions to these pay-to-read journals in order to provide access to university students and faculty or to the citizens of their country; however, people in lower income locations may depend on open access journals. Many changes have taken place in the open access space: some beneficial (Gadd \& Troll Covey, 2019) and some less so (Bolshete, 2018).

Creative Commons (https://creativecommons.org/about) works similarly to open access, except on a larger scale, as it applies to many types of work, including visual work. Creators utilize a creative commons license to allow others to use their work without violating copyright restrictions. As the Creative Commons website states, "By helping people and organizations share knowledge and creativity, we aim to build a more equitable, accessible, and innovative world."

\section{Building Community}

Open access journals and Creative Commons grew out of the desire to share one's knowledge. This sharing fits with being an engaged intellectual and with the concept of Community of Practice (Kevany \& MacMichael, 2014; Wenger, 1998). Communities of practice are groups of people, which are often loosely knit, bound together by the pursuit of mutual interests, goals, and endeavours. For instance, people who share a common concern about climate change have the related goal of reducing human produced greenhouse gas emissions (although they may advocate different methods of achieving that reduction) and work to involve the public, government, and institutions in changing attitudes and behaviors. The community of practice's members share common vocabulary, such as "greenwashing," "anthropocentric," and "carbon neutral."

As IT-aided communication plays an ever-increasing role in society, it can be used to build communities where engaged intellectuals can participate. However, there seem to be competing 
consequences of IT's growing role: will IT impair the bonds between people (Hunt, Marx, Lipson, \& Young, (2018), or can IT be a tool for building community (Naslund, Aschbrenner, Marsch, \& Bartels, 2016)? Engaged intellectuals will want to be models for growing a supportive sense of community. For example, in any social movement, differences of approach emerge; the question becomes whether people negotiate these differences in a win-win community manner or in an Iwin-you-lose manner which impedes community building.

Additionally, social media offers many opportunities for making engaged intellectuals' work immediately available. Blogs, video blogs, and podcasts also provide vehicles for immediate dissemination. In each case, a major part of the effort lies in promoting the vehicle, e.g., the Instagram feed or the podcast, so as to have more viewers, listeners, etc. (Podcast.co, 2019).

Fortunately, there seems to be a growth in academia and elsewhere in the use of the terms that map well with "community," including the term "social," e.g., the creation of new fields, such as social geography (Enos, 2017) and even social physics (Pentland, 2014). Possibly, this increase reflects growing recognition that we humans are all positively interdependent with one another, i.e., what benefits one benefits all and what harms one harms all (Renard \& Davis, 2019). The presence of positive interdependence has long been recognized among the members of sports team, orchestras, and theatre troops, but its ubiquity in settings where humans impact one another often goes unrecognized, as does positive interdependence among humans and other animals, e.g., the fact that by saving tigers and their habitats, humans assist in their own survival.

One way that engaged intellectuals can build community is, rather than working alone or with a small number of colleagues, engaged intellectuals can work with organizations or even start their own organizations. For example, Jane Goodall began her research with chimpanzees in the 1960s, but by the 1970s, she had realized that she needed to turn to activism instead of scholarship in order to confront the poaching, habitat destruction, and bushmeat trade that were threatening the chimpanzees' survival. Thus, in 1977, she helped to form the Jane Goodall Institute (JGI, 2019). Today, the organization spreads the message of environmental concern and animal welfare in schools in many countries around the world.

Similarly, in the 1990s, a group of members of the TESOL (Teachers of English to Speakers of Other Languages) organization collaborated to form the TESOLers for Social Responsibility Interest Section (2019) within the larger TESOL organization. The interest section reaches out to colleagues with ideas on how to integrate social issues in the teaching of English 
and other additional language situations. Similar organizations exist in other professions, e.g., Physicians Committee for Responsible Medicine (2019).

In addition to joining professional organizations, engaged intellectuals can also join advocacy organizations that cater to all types of people, such as Citizen Action for Tigers (n.d.), the organization that enabled the author to become engaged on behalf of tigers. Engaged intellectuals can contribute their professional skills and perspectives to the service of the organizations' goals, e.g., as noted earlier in this paper, the author used his language skills to help write an article for the popular media on the incident when the two tigers walked into a village. Many NGOs are in great need of help in a wide variety of areas.

\section{Reflections}

We live in exciting times. Schwab (2017), founder and executive chair of the World Economic Forum says that we are in the midst of a Fourth Industrial Revolution. Part of this revolution is technological, involving AI, IoT, quantum computing, and other innovations that humans can use either to address the climate crisis and other problems or to make them worse. However, the most important part of the Fourth Industrial Revolution lies less in the technology than in changing our attitudes towards progress. Is progress measured in terms of how much we can buy, how many distant destinations we can visit, or instead, can we measure progress, not in externals, but in internals? This means focusing on appreciating the growth of our lifelong learning, our selfdirection, our civic literacy, and concerned citizenship, and our feeling of community in order to help our fellow humans and other fellow earthlings live in harmony on the planet. Being an engaged intellectual certainly fits this perspective.

However, everyone has to figure out for themselves how being an engaged intellectual works best for them at particular times and places in their lives. Perhaps early in their career, they need to focus on building their professional skills, or maybe they need to save money for family reasons or to achieve some degree of financial independence, as engaged activities sometimes pay little or nothing, as well as carrying some risk to one's job security. Another essential aspect of being an engaged intellectual involves figuring out what type of engagement works best. For example, I was recently speaking to a scientist who worked in the chemicals industry while being a scuba diving instructor on the side. One of her roles with a large international chemical company was making packaging, but she decided to quit after, while scuba diving, she had encountered so 
much of her handiwork at the bottom of the ocean as plastic waste. Knowing the consequences for marine life of that plastic, her conscience would not allow her to continue.

Some people might think that intellectuals engaged in teaching do not have this same quandary about the impact of their work as was experienced by the chemist, as according to the following quote from Nelson Mandela that I saw today in a friend's email signature (https://www.google.com/doodles/nelson-mandelas-96th-birthday), "Education is the most powerful weapon we can use to change the world." However, my many years teaching English to both first and second language users of English lead me to question assumptions about the impact of teaching. First of all, many of my students come to class unmotivated to learn, and despite my use of a bag of tricks informed both by research and practical experience, many of these students leave my class still unmotivated. Yes, education has the potential to be powerful, but so often the power of this tool is dulled by circumstances.

Another question that engaged intellectuals confront asks about what our students, whether they are face-to-face students or people who learn with our publications, do with the tools we help them learn. Obviously, language, thinking skills, social skills, and other areas of our curriculum can be used for both helpful and harmful purposes. Thus, the path from our intention to the behaviors of our students is fraught in multiple ways: will students be motivated to learn what we hope to teach; will they use what they learn for purposes that might make the world a better place; and who knows what will, in the end, make the world a better place or even what it means for the world to be a better place (cf. Chau \& Kerry, 2008).

The above uncertainties notwithstanding, we can be fairly certain of some realities that cry out for urgent change. These include that hundreds of millions of people lack sufficient food, lack clean water, and lack sanitation facilities. At the same time that money could make a major dent in these problems or even eliminate them, $\$ 1.8$ trillion is spent on military budgets (Stockholm International Peace Research Institute, 2019). Another urgent global problem lies in the hundreds of billions of land and marine animals who die needlessly every year to produce food for humans (Sentient Media, 2019), food that harms human health (NutritionFacts.org, n.d.), at the same time that the production process for animal-based foods hastens the apocalypse of climate change (Schiermeier, 2019). Therefore, despite the uncertainties faced, we engaged intellectuals have to continue, and perhaps intensify, our engagement and seek to involve more intellectuals and others. 


\section{Conclusion}

The goal of this article has been to encourage fellow intellectuals to spend a significant amount of their time engaged in activities that directly impact society. In other words, intellectuals should make frequent trips outside the ivory tower in order to use their talents on real world concerns. In this way, intellectuals can hone their skills, increase their motivation, and flex their altruism muscles. This article has provided some examples of intellectuals engaging with real world issues and provided suggestions on how such engagement might be done.

\section{References}

80,000 hours. (2019). Retrieved from https://80000hours.org/.

Allport, G. W. (1954). The nature of prejudice. Cambridge, MA: Perseus Books.

Attali, Y., Laitusis, C., \& Stone, E. (2016). Differences in reaction to immediate feedback and opportunity to revise answers for multiple-choice and open-ended questions. Educational and Psychological Measurement, 76(5), 787-802.

Azmi, N. J., Rashid, R. A., \& Wahab, Z. (2018). Young girls' perception of beauty in Disney princess Movies. International Journal of Asian Social Science, 8(9), 686-693.

Barlett, C. P., Vowels, C. L., \& Saucier, D. A. (2008). Meta-analyses of the effects of media images on men's body-image concerns. Journal of Social and Clinical Psychology, 27(3), 279-310.

Birney, E., Hudson, T. J., Green, E. D., Gunter, C., Eddy, S., Rogers, J., ... \& Berglund, L. (2009). Prepublication data sharing. Nature, 461(7261), 168-170. https://doi.org/10.1038/461168a

Bolshete, P. (2018). Analysis of thirteen predatory publishers: A trap for eager-to-publish researchers. Current Medical Research and Opinion, 34(1), 157-162.

Campbell, J. (2003). The hero's journey: Joseph Campbell on his life and work (Vol. 7). Novato, CA: New World Library.

Chau, M. H., \& Kerry, T. (Eds.) (2008). International perspectives on education. London: Continuum/Bloomsbury.

Citizen Action for Tigers. (n.d.). Malaysia has less than 200 wild Malayan tigers left. Retrieved from https://www.citizenactionfortigers.my

Conte, S. (2019). Making the choice: Open access vs. traditional journals. Retrieved from https://www.aje.com/arc/making-the-choice-open-access-vs-traditional-journals.

del Rozario Zavala, M., \& Stoehr, K. J. (2019). From community exploration to social justice mathematics: How do mathematics teacher educators guide prospective teachers to make the move? In T. G. 
Bartell, C. Drake, A. R. McDuffie, J. M. Aguirre, E. E. Turner, M. Q. Foote (Eds.). Transforming mathematics teacher education: An equity-based approach (pp. 91-103). New York, NY: Springer.

Denny, F. (2019). "Do you have Batman shoulders?" Middle school math students explore the disproportions of their favorite childhood toys. Rethinking Schools, 34(1). Retrieved from https://www.rethinkingschools.org/articles/do-you-have-batman-shoulders

D'Rozario, V. (2019, August 3). Commentary: Tigers belong in the wild, not in our homes, the streets or farms. Channel News Asia. Retrieved from http://www.channelnewsasia.com/author/11766010

Effective altruism. (2016). Introduction to effective altruism. Retrieved from https://www.effectivealtruism.org/articles/introduction-to-effective-altruism.

Eshach, H. (2007). Bridging in-school and out-of-school learning: Formal, non-formal, and informal education. Journal of Science Education and Technology, 16(2), 171-190.

Extensive Reading Foundation. (n.d.). What is ER? Retrieved from https://erfoundation.org/wordpress/what_is8

Gadd, E., \& Troll Covey, D. (2019). What does 'green' open access mean? Tracking twelve years of changes to journal publisher self-archiving policies. Journal of Librarianship and Information Science, 51(1), 106-122.

Gardner, H. (1993). Multiple intelligences: The theory and practice. New York, NY: Basic Books.

Gender. (2019). In Oxford Dictionary online. Retrieved from https://www.lexico.com/en/definition/gender

Gilquin, G., \& Jacobs, G. M. (2006). Elephants who marry mice are very unusual: The use of the relative pronoun who with nonhuman animals. Society \& Animals, 14(1), 79-105. http://www.animalsandsociety.org/assets/library/597_sa1417.pdf

Gronn, P. (2002). Distributed leadership as a unit of analysis. The Leadership Quarterly, 13(4), 423-451.

Hunt, M. G., Marx, R., Lipson, C., \& Young, J. (2018). No more FOMO: Limiting social media decreases loneliness and depression. Journal of Social and Clinical Psychology, 37(10), 751-768.

International Ecolinguistics Association. (2019). About. Retrieved from http://ecolinguisticsassociation.org

Ivory tower. (2019). In Merriam-Webster online. Retrieved from https://www.merriamwebster.com/dictionary/ivory\%20tower

Jacobs, G. M., \& Fong, S. J. (2020). Perspectives on a 2019 tiger-human interaction incident in Malaysia. ECO-REBEL 6(1), 41-51. Retrieved from https://periodicos.unb.br/index.php/erbel/article/view/29896

Jacobs, G. M., Goatly, A., \& Ming, J. (1995). Language and the environment. PASAA, 25, 54-63. 
Jacobs, G. M., \& Power, M. A. (2016). Student centered learning: An approach to fostering democracy in schools. Beyond Words, 4(2), 79-87. Retrieved from http://journal.wima.ac.id/index.php/BW/article/view/884/pdf

Jacobs, G. M., \& Renandya, W. A. (2019). Student centered cooperative learning. Singapore: Springer Nature.

Jessup-Anger, J., Armstrong, M., Kerrick, E., \& Siddiqui, N. (2019). Exploring students' perceptions of their experiences in a social justice living-learning community. Journal of Student Affairs Research and Practice, 56(2), 194-206.

JGI (Jane Goodall Institute). (2019). Our story. Retrieved from https://www.janegoodall.org/our-story.

Johnson, D. W., \& Johnson, R. T. (2009). An educational psychology success story: Social interdependence theory and cooperative learning. Educational Researcher, 38(5), 365-379.

Jones, S. (n.d.). What is an engaged intellectual? Retrieved from https://engagedintellectual.wordpress.com/about

Kenney, M. (2019). Why I don't teach the hero's journey. Rethinking Schools, 34(1). Retrieved from www.rethinkingschools.org/articles/why-i-don-t-teach-the-hero-s-journey.

Kevany, K. M., \& MacMichael, M. (2014). Communities of knowledge and knowledge of communities: An appreciative inquiry into rural wellbeing. Gateways: International Journal of Community Research and Engagement, 7(1), 34-51. doi:10.5130/ijcre.v7i1.3392

Kind, S. (2016, November 1). Critical friends protocol. Video file retrieved from https://www.youtube.com/watch?v=5aZSITkOLOc.

Kristian, F. (2019). What makes a hero? theorising the social structuring of heroism. Sociology: The Journal of the British Sociological Association, 53(1), 87-103. doi:http://dx.doi.org/10.1177/0038038518764568

Lieberman, M. (2013). The social brain and its superpower. [Video file]. Retrieved from https://www.youtube.com/watch?v=NNhk3owF7RQ

Maslow, A. H. (1968). Toward a psychology of being ( $2^{\text {nd }}$ ed.) New York, NY: Van Nostrand.

Naslund, J. A., Aschbrenner, K. A., Marsch, L. A., \& Bartels, S. J. (2016). The future of mental health care: Peer-to-peer support and social media. Epidemiology and Psychiatric Sciences, 25(2), 113-122.

NutritionFacts.org. (n.d.). Animal products. Retrieved from https://nutritionfacts.org/topics/animalproducts/

O'May, F., Gill, J., McWhirter, E., Kantartzis, S., Rees, C., \& Murray, K. (2016). A teachable moment for the teachable moment? A prospective study to evaluate delivery of a workshop designed to increase knowledge and skills in relation to alcohol brief interventions (ABIs) amongst final year nursing and occupational therapy undergraduates. Nurse Education in Practice, 20, 45-53. 
Palincsar, A. S. (1998). Social constructivist perspectives on teaching and learning. Annual Review of Psychology, 49, 345-375.

Physicians Committee for Responsible Medicine. (2019). About us. Retrieved from https://www.pcrm.org/about-us.

Podcast.co (2019). 10 quick ways to promote your podcast. Retrieved from https://www.podcast.co/reach/promote-your-podcast

Quinn, F., Castéra, J., \& Clément, P. (2016). Teachers' conceptions of the environment: Anthropocentrism, non-anthropocentrism, anthropomorphism and the place of nature. Environmental Education Research, 22(6), 893-917.

Renard, D., \& Davis, J. G. (2019). Social interdependence on crowdsourcing platforms. Journal of Business Research, 103, 186-194.

Rothschild, M. (2003). Edward W. Said. The Progressive, 67(11), 4.

Schwab, K. (2017). The fourth industrial revolution. New York, NY: Currency.

Schiermeier, Q. (2019). Eat less meat: UN climate-change report calls for change to human diet. Nature, 572(7769), 291-292. doi: 10.1038/d41586-019-02409-7

Sentient Media (2019). How many animals are killed for food every day? Retrieved from https://sentientmedia.org/how-many-animals-are-killed-for-food-every-day/

Stockholm International Peace Research Institute (2019). World military expenditure grows to \$1.8 trillion in 2018. Retrieved from https://www.sipri.org/media/press-release/2019/world-militaryexpenditure-grows-18-trillion-2018

Suppiah, P. C., \& Kaur, S. (2018). Transnational sex workers in Malaysia: Methodological challenges in data collection. Journal of Modern Languages, 28, 118-136. Retrieved from https://jml.um.edu.my/article/view/15615.

This speculative SpaceX timeline reveals roughly when, where, and how Elon Musk plans to colonize Mars. (October 14, 2018). Business Insider. Retrieved from https://www.businessinsider.sg/elon-muskspacex-mars-plan-timeline-2018-10/?r=US\&IR=T

TESOLers for Social Responsibility (2019). Mission statement. Retrieved from https://sristesol.wordpress.com/missionstatement.

Vygotsky, L. S. (1978). Mind in society (ed. by M. Cole, V. John-Steiner, S. Scribner, \& E. Souberman). Cambridge, MA: Harvard University Press.

Wenger, E. (1998). Communities of Practice: Learning, meaning, and identity. Cambridge, United Kingdom: Cambridge University Press. 


\begin{abstract}
About the Author
Dr George M Jacobs writes and organizes for a more harmonious world. In addition to the Centre for a Responsible Future, George is active with the International Ecolinguistic Association, Extensive Reading Foundation, and Kampung Senang Education and Charity Foundation. Many of his papers are available free at georgejacobs.net, and his email is george.jacobs@gmail.com.
\end{abstract}

